\title{
A Path Towards a Possible Future - Adult Students' Choice of Vocational Education
}

\author{
Tobias Karlsson $^{1}$ (D) Karolina Muhrman ${ }^{1}$ (D) Sofia Nyström ${ }^{1}$ (D)
}

Received: 20 January 2021 / Accepted: 12 October 2021 / Published online: 22 October 2021

(C) The Author(s) 2021

\begin{abstract}
Today's society is characterized by high unemployment, a prevailing trust in and demands for an academic degree, and an emphasis on the individual's own responsibility for their educational choices. This study aims to examine adults' vocational education choices, their intentions in connection with municipal adult education (MAE) studies, and how this relates to identity formation. The study is based on 18 interviews and compares students from two vocational MAE training programmes in assistant nursing and floor laying. The analysis has identified different pathways concerning adult students' decisions to enrol in municipal adult education and a specific vocational education and training (VET) programme. We see educational choices and paths in terms of underlying causes or as forward-looking rationalities. The results show that the process of identity formation is larger than simply one of vocational becoming within a vocational community of practice, since MAE studies involve a student's whole being, including both their personal identity trajectories and their vocational identity formation. With this article we hope to provide a foundation for a pedagogical discussion about student intentions, focusing on how different subjectivities affect students with regard to their future vocational becoming.
\end{abstract}

Keywords Adult student $\cdot$ Identity $\cdot$ Municipal adult education $\cdot$ Educational choice $\cdot$ VET

Tobias Karlsson

Tobias.Karlsson@liu.se

Karolina Muhrman

karolina.muhrman@liu.se

Sofia Nyström

sofia.nystrom@liu.se

1 Department of Behavioural Sciences and Learning (IBL), Linkoping University, Linkoping, Sweden 


\section{Introduction}

According to the OECD (2020), the demands of the twenty-first century make lifelong learning a central concept when educational issues are discussed. The term 'lifelong learning' involves flexible educational pathways that are available throughout life, not just when one is young, which makes adult education central. Sweden has a long tradition of adult education, and students in municipal adult education (MAE) comprise 4\% of the adult population aged 20-64 (SNAE, 2017). This makes Sweden one of the countries with the highest numbers of adults participating in adult education.

The demands placed on education are constantly increasing. Knocke and Hertzberg (2000) state that, today, all occupations require upper secondary education or a degree. Given this increasing belief in education, it is low-educated citizens who are particularly vulnerable in today's labour market. Enrolling in MAE could mean a second chance for those who have been unable to complete upper secondary education, or for newly arrived migrants who lack education (Hägersten, 2004).

The document "The Swedish strategy for lifelong learning. A summary of principles and orientations" (SGO, 2007) describes the individual's needs and opportunities on which the organization of adult education should focus. However, in relation to lifelong learning, there is also an emphasis on the individual's own responsibility to be familiar with the educational opportunities that exist and the requirements that are placed on the various educational alternatives. The OECD (2020) also emphasizes adult education as an important way of bridging gaps in society, highlighting the importance of education for socio-economically weak groups or people with an immigrant background in order to lift countries' economies, and stressing the importance of people utilizing their talents.

Today's high levels of unemployment, the prevailing trust in and requirements for an academic degree, and the emphasis on the individual's own responsibility for their educational choices make it interesting to study why students have chosen to enrol in adult education and what they hope to achieve with their studies. This article is part of a larger study about students' identity formation in vocational adult education. Here, the focus is on students' encounters MAE. The aim is to study adults' vocational education choices, their intentions with MAE studies and how this relates to identity formation. The study compares two vocational MAE training programmes in assistant nursing and floor laying.

\section{The Context of the Study}

MAE has existed in Sweden since 1968, and now has more students than upper secondary education. The Education Act stipulates that MAE has a threefold function: a compensatory function, a civic and democratic function, and a labour market function (SFS 2010: 800). The municipalities must offer MAE to anyone 
over the age of 20 who has not completed compulsory school, as well as to those who want to complete their upper secondary education grades or who want to supplement their upper secondary school grades to be eligible for higher education (SNAE, 2020). Many municipalities also offer MAE to those with previous education who want to study vocational education in order to change professions. MAE is free, and these studies also bring entitlement to study support. Today, most of the students who study basic level MAE courses are foreign-born, while two-thirds of those who study courses at upper secondary school level, which includes vocational education, are Swedish-born. In many cases, vocational MAE plays a significant role for integration, as many newcomers study vocational MAE to become established in the labour market (see Andersson \& Muhrman, 2019).

The courses that are included in MAE at upper secondary level have the same syllabus as for upper secondary school courses. However, they can be organized within different course packages that can be linked to upper secondary vocational education or to specific occupations to varying extents. There are also national vocational training programmes (otherwise called course packages) lasting 0.5 to 1.5 years that are intended to match the needs of the labour market (SNAE, 2020).

\section{Assistant Nurse and Floor Laying Training Within MAE}

Almost all municipalities that conduct MAE offer training places for assistant nursing (AN). Eight of the ten MAE courses with the largest numbers of participants at national level are courses that are included in the AN course package. Between 2008 and 2013, MAE accounted for about half of those who trained within the framework of care and nursing (Statistics Sweden, 2015). The group of MAE students is heterogeneous with different purposes, and many of those who start studying within MAE drop out of their studies. However, of the five most commonly completed courses, all are included in the national course package that leads to a vocational degree in AN (SNAE, 2018b).

The MAE course package for floor laying (FL) includes courses from the building and construction programme specializing in flooring. A large part of the FL training within MAE consists of workplace-based learning, and the training programme can also be given as an apprenticeship programme. Fewer municipalities have internal provision within MAE for FL training, compared with AN training. On the other hand, there are private companies offering FL training that the municipalities can hire and, as with AN, FL is described as an occupation with a shortage of workers and with good opportunities for work after completing the training.

In this study, the AN training programme spans 1.5 years and the FL training programme spans one year. They both included courses focusing on teaching what students need to know to start working in their vocations. This compares with regular upper secondary VET, which also includes courses in mathematics, English, social science, history and so on, which in a broader sense prepares for community life or further studies, and is therefore three years long. 


\section{Previous Research}

When reviewing the international research to understand what constitutes a vocation and vocational identity formation, there is a discussion on a conceptual level between 'vocation' and 'occupation'. A vocation is dependent on a person and the community of craftsmen, and mirror their goals, learning and personal trajectories. An occupation, on the other hand, is socially defined and reflects social needs and imperatives (Billett, 2011; Jørgensen, 2013). This distinction is important in this study, since it concerns students' subjective meaning of a vocation and their choice to enrol in adult education. However, the choice of which vocation to choose is also influenced by structures, symbols and identities in society today (Hägerström, 2004). Billett's (2011, p. 66) definition of vocation includes both individual aspects and the relationship to the social aspect:

Personally directed and assented by often socially derived practices that reflect an individual's enduring aspirations and interests, and are usually manifested in culturally and historically derived activities that may carry worth for both the individual and their community.

Studies on identity formation often focus on how a vocation is learned in education or in working life (Hodkinson et al., 2008). The results indicate a discrepancy between these two areas regarding which knowledge is prioritized and how to practise a vocation (e.g. Billett, 2011). Studies also emphasize (e.g. Koniordos, Brown, Strietska-Ilina, \& Patiniotis, 2001) that the vocation as such may not be the significant outcome for everyone enrolled in vocational education. Koniordos et al. (2001) argue for a difference between "making a life" and "making a living", since individuals give different meanings to their choice of vocational education and their subsequent vocation, which can change during studies or in working life (Billett, 2011; Klope, 2015). Jørgensen (2013) describes a group of self-assured and well-educated people who form their work identity on the basis of their individual career rather than the profession. Even if they identify with their job, they see this as temporary and they are described as having a distanced professional identity.

Klope's (2015) study shows that the choice of vocational education is an important process of identity formation. It could be either a specific choice towards something - "I want to become a hairdresser" - or a choice to get away from something - "I do not want to work in an office". Not only is it a choice of a future vocation, it can also be a choice which grants students a sense of belonging outside work life. Lagercrantz All (2017) has studied student experiences of an adult education programme in health and social care, and the results show that this programme gives not only vocational knowledge but also language skills, cultural competence and personal development. Similar aspects are emphasized by Assarsson and Sipos Zackrisson (2005) in their study of how identities are created in adult education. One central aspect is how the participants demonstrate different repertoires in relation to their studies: making a living, learning, earning credits and self-realization. These repertoires and the participants' identities are 
also related to the individuals' life situations. In addition, Wojecki (2007), who studied interrelationships between identity and learning for adult learners, found that both students' prior educational experiences and how they talk about their experiences affect their educational engagement.

Rothes et al's., (2014) study shows that adults have both intrinsic motives and extrinsic, job-related motives for enrolling in adult education. One common intrinsic motive is identity-based, and relates to "wanting to improve one's status and selfworth" (p. 946). They also describe how some adults enrol in education for social motives, like meeting new people. However, studies also show that several different variables can influence adult students' educational choices, such as experiences from previous education, their social environment, their parents, their experiences of work and gender norms (see e.g. Dæhlen, 2005; van Tuijl and van der Molen 2016). Furthermore, according to Ferm, Persson-Thunqvist, Svensson and Gustavsson (2019), who investigated the learning trajectories of upper secondary industrial students, social background can be an important reason for a student choosing education but "not necessarily for committing" (Ferm et al., 2019, p. 104).

Many prospective MAE students also receive suggestions from administrators at the Swedish Public Employment Service (Arbetsförmedlingen) or study counsellors about vocational MAE that leads to jobs. According to study counsellors, many prospective students with foreign backgrounds choose training to become assistant nurses, since they know it is a good opportunity to gain access to the labour market (Andersson \& Muhrman, 2019). Studies also show that study guidance plays a crucial role in students choosing education in a different field than expected (Borghans et al., 2015). However, research by Eriksson et al. (2018) shows that there are sometimes problems with study guidance, with students without an academic background describing a lack of information about higher education and only receiving information about vocational education. According to the authors, this risk leads to unequal class structures being reproduced, so that the choice of education is not expanded with new perspectives but is limited to students' own knowledge of the labour market and the knowledge they gain from their families.

\section{Analytical Perspectives on Learning and Sense of Self}

In this article, the concept of identity plays a central role in students' vocational development since education and work are important in terms of how the students see themselves. The development of a vocational identity is an ongoing learning process where the student's cognitive resources are engaged in learning activities and interactions. It is a process of both thinking and acting, which is directed by the student's subjective disposition (Billett, 2010). Subjectivity, as described in this article, is inspired by Billett (2010) and Billett and Somerville (2004), i.e. subjectivity as the student's "manifestation and projection of a sense of self that stands to direct their agency" (Billett, 2006, p. 3). The sense of self guides the student's intentions, thinking and actions or, as Billett (2006) argues, the concept has both personal and societal connotations. He stresses that "Socially, there are forms of institutional, normative and discourse practices that are associated with individual's identity" (ibid. 
p. 7). Furthermore, sense of self helps the individual to make sense of the social context; despite being both shaped and limited by different communities of practice, the student is not only subjugated by the social world but also possesses agentic qualities that affect their own development. Because the student is both subjected to and has the power to affect the practice, understanding personal agency is vital in order to understand the relationship between the personal and the social.

Similar to Wenger (1998), Billett (2010) views a community of practice as a pedagogical system that is more than a system of potential personal enactment and, since the student's reproduction of a practice is enacted through their interpretation of the practice, the overall learning process (development of vocational knowledge, repertoire, sense of self, identity) will benefit from understanding the student's interests and engagement in the vocation. Therefore, identity within this context is defined as how and what individuals identify themselves with, as well as what they wish to be identified with (Billett, 2010). These lines of argument have a resemblance to Wenger's (1998) thoughts about identity as multimembership. He stresses that we belong to many different communities, being full members of some and more peripheral in others. All of these communities contribute to the construction of identity in one way or another. The concept of identity therefore always involves an experience of multimembership and reconciliation, i.e. maintaining one's identity across different communities of practice. In line with Wenger's definition of identity, people participate in different communities where they choose to show different parts of their identities, behave differently and take on different perspectives as a way of coordinating their identity. The maintenance of an identity across different communities of practice has similarities with what Billett and Pavlova (2005) argue to be a process of how to exercise the sense of self in a specific practice. Furthermore, they argue for a connection between identity, interests and quality of work and, in an educational context, the student's intentions are especially important. Regarding reaching educational goals, the student's intentions could be considered to be just as important as those proposed by others (Billett \& Pavlova, 2005, p. 209), and if learning and development are to be understood, attention to intentionality and subjectivity is needed (Billett \& Somerville, 2004).

\section{Method}

This article is based on a qualitative interview study (initiated by Karlsson) with adult students encountering MAE. A qualitative research design with semi-structured interviews was chosen since it help us to see the world through the eyes of the informants (Kvale \& Brinkmann, 2015). The interviews were conducted at the beginning of the training programmes with AN and FL students. The training programmes were selected based on gender differences, with AN representing a female-dominated vocation and FL a male-dominated one. The selection was also made based on the structures of the training programmes, with AN training having a relatively theoretical character and FL training being structured more as an apprenticeship with more practical work. Two schools were selected based mainly on accessibility. 
The interviews were conducted with the students at their respective schools by Karlsson during autumn 2019 and spring 2020. There were two male and eight female AN students and eight male FL students. The interviews were semi-structured, with relatively open questions that gave the informants a chance to develop their answers. The interview guide covered questions about the informant, routes into MAE, educational goals, vocational competence and vocational identity. The interviews varied between 20 and 50 min in length. In some cases there were minor language barriers, which is perceived to have affected the length of the interviews.

The informants received both written and oral information about the purpose of the study, confirming that all data would be confidential and that they had the right to choose to end their participation in the study at any time. Written approval was collected from all the informants. The interviews were recorded using a dictaphone, anonymized and stored in accordance with the guidelines for information security at Linköping University.

The interviews were transcribed in their entirety and then analysed using a thematic analysis (Braun \& Clarke, 2006; Clarke \& Braun, 2017). More specifically, this involved reading through all our interview transcripts together to familiarize ourselves with the material as a whole, before starting the coding and categorization work. Guided by the research aim, the analyses focus on students' encounters with MAE. The theoretical perspective guided the analytical attention towards students' sense of self (e.g. Billett, 2010) and how their identity was maintained across different communities of practice (see Wenger, 1998). Several themes were identified concerning adult students' decisions to enrol in MAE and a specific VET programme. These themes were processed and subsequently categorized to visualize different phenomena, which in turn were described in text supported by quotations and compilations.

\section{Findings - the Way In}

The analysis has identified different themes concerning adult students' decisions to enrol in MAE and a specific VET programme. We see these decisions more as underlying causes behind the educational choice and paths highlighting more forward-looking rationalities. These choices or paths are not a representation of one student's answers; rather, they are an amalgamation of ideas from various students. The students are simultaneously talking about multiple paths, and the educational choice they have made is a hodgepodge of different rationalities.

\section{A Pragmatic Choice}

A pragmatic choice is generally the most common reason behind students' choice of VET. This choice is characterized by what the students see as an acceptable profession. It is not something that is bad, but it is not necessarily something they are passionate about. The pragmatic choice is in many ways the path to good job opportunities with education that is short in duration. This choice is also characterized by 
the students' desire to work with their hands, to do something 'practical', and was expressed in the form of "working with caregiving" rather than working in AN, or "working as a craftsman" rather than working in FL. For example, Ayana who just wants to help others, says: "I wanted to help, especially the elderly, children and animals", or Florim, who explains: "I like doing more, creative, like, using your hands when you work; so, more like, craftsmanship and that."

The main goal is not necessarily to pursue a specific vocation; it is rather becoming someone who does something in a certain vocational area. These students intend their training to be part of something larger and shared by a community of workers. There are many ways to work as a craftsman or a caregiver, but based on the students' prerequisites and circumstances, these VET programmes were perhaps the best choices. It should be clarified that the pragmatic choice is not seen as a failure, or 'the least bad', from the students' perspectives, and none of the students expressed such a thing. Rather, they expressed that they chose this programme because it was the most interesting educational path relative to the opportunities offered by their life situations. In theory, the students could choose from all of Sweden's MAE programmes, but issues such as housing, commuting time, family situation and job opportunities influenced their choices. Take Florim, for example, who wanted to change jobs, partly because he was not fond of his current job situation but also because he had recently become a parent; the goal was to become a craftsman, ideally a carpenter, but the nearest carpentry training programme was too far away geographically.

\section{One Path Among Others}

Not all the students' choices were really about a particular vocation. For several of them, the choice was more about an area such as caregiving or crafts. However, there were students who had wider variations in their education paths.

AN students in particular talked about alternative educations and had a wide variety of paths such as hairdressing, automotive engineering, technical engineering, child recreation, etc. Among the FL students, there was an overall interest in paths leading to "working as a craftsman", although getting a job was also a common reason. Three of the FL students had even thought about AN, for example Farid who chose between FL, welding and AN. Despite the discrepancy between the work tasks involved in AN and FL (or welding), he explained that he likes helping people and that it should be easy to get a job in healthcare. Similarly, Fatos mentioned that many who have recently come to Sweden are encouraged to study a programme to get a job, but added that it was not something for him:

I could not take the, like most who come to Sweden, AN training, I just didn't want to go around and take care of people all day. I am not a person who can take care of other people but this, maybe, it seems like this can go well. [...] if you take the AN programme you need to take care of old people [...] giving medicine and all that. I am not that kind of person. I like other people, I am a nice guy, but I don't want to go around and help with everything, wiping their 
poop and so on... Since I was younger, I liked building things but not just with construction, floors would suit me, I thought.

As Fatos points out, the choice of education is not just about the opportunity to get a job. Thinking that the work tasks are 'fun' is also something that guides the choice of education. In other words, the conceivable future is a future where you do something you like, or at least do not dislike.

\section{A Choice Based on Prior Experience and External Influence}

Some students' choice of education is also based on previous experience of the vocation, external influence, or a combination of the two. Only two of the interviewed AN students - the two men - lacked experience of care work. The others had work experience as care assistants, through either work or work experience placements via the Swedish Public Employment Service, ranging from a few weeks to several years. Amanda explains:

Well, I first got a summer job at the retirement home and thought it was really nice, then they asked if I wanted to work as a temp and at first, I just said 'yeees?', like, I didn't really want to work with old people because I thought it was gross with all that secretion and all that faeces, but now I don't mind and I think it's nice, socially, and cosy.

For the FL students, the situation was different. Some students had prior experience of working with building and construction, but FL as a vocation was, overall, a relatively new discovery. Most of the students had come into contact with the FL vocation for the first time at a job and MAE fair which opens up new possibilities. Farid says:

I thought that, since I have worked a little as a carpenter in my home country, it looks pretty much the same, I thought it was interesting in my home country and now I think this is interesting, laying some plastic mats and so on.

The combination of experience and influence can also be seen with the AN students. For example, Anna got a work experience placement as a care assistant at the same time as her grandmother suffered from a serious illness. Here, educational and vocational interest had grown in connection with other life experiences over a longer period of time. Through external influence, in the form of visiting a job/MAE fair and meeting the teachers and study councillors, her choice based on previous experiences became clear.

External influence can also involve being encouraged in some way by someone, like Ajda, who had been told by a study counsellor that she was suitable for AN. Another example of external influence can be seen in the case of Farid, who had considered both the health and social care and child recreation programmes, but decided on FL instead after a conversation with study counsellors. Farid says: "I think I like working with building and construction and so on, but in Sweden, you know, for us, it's cold and I could not work outdoors. Floor layers work indoors." 


\section{A Path with Possibilities}

Different VET programmes come with a number of possibilities, in the form of job and career opportunities as well as access to tertiary education. Every AN student expressed, in some form, an idea about further studies after MAE and an awareness that AN training can "lead to higher studies". However, this is not an integral path for everyone. If students want to study at university, they need more qualifying courses either during or after their MAE, and it is unclear to what extent students in general are aware of this. Alea was the only AN student who both explained that she wanted to become a nurse later on and knew which additional courses she needed (which she was also taking). Abena also expressed an idea about further studies, she likes the AN job but views MAE as a steppingstone to either a job or tertiary education: "I think it is interesting to study health care, I do! I have not yet decided [...] I would like to continue (studying), or else I will just stay as an assistant nurse."

Altair was the one who most clearly expressed that his end goal was not to work in AN. Rather, he wanted to take up his previous vocation as a dental technician, which he had before coming to Sweden. He says: "For me, I want to learn a lot, this is interesting to me, learning something new, but at the same time I am not aiming for an assistant nurse's job, it's boring."

For many of the FL students, MAE is not emphasized as a path towards higher education. Instead, they see themselves following a career within the FL occupation. For some, like Florim, their future professional life is strongly linked to their education and the path that follows after graduation. Florim says:

Well, at the moment I'm eager to work with this, I have been in contact with the company where my brother-in-law works to get me WBL [work-based learning] there and probably an apprenticeship, so I probably have a place there afterwards. [...] Then maybe, in the future, you get to see if you can make something of your own. It's fun too; in any case you have a goal, so if you learn and get all the stuff in, we'll see what it leads to.

After their training, the students must first work as an apprentice before becoming a fully paid floor layer, and some of them want to run their own business or specialize after that. For Florim, there is a plan involving a steady progression within his VET programme and between education and working life, right from the beginning. But even among FL students, there are thoughts of further studies. Amanuel dreams of making a career and becoming a boss, but can also imagine studies at university. Amanuel says:

I want to be a boss too! You learn, you educate yourself, you gain experience, and you get better and better so that in the future, you can have your own company as well [and that] takes a lot, you have to have experience, educate yourself, know a lot about many things, learn to study more maybe? First you are a regular floor layer but then, there is university and there is more education.

For others, the career path is more unclear. Some see themselves working in FL, but may do something else in the future. Fikru wants to work as a floor layer, 
but since he has previously worked with elderly care and as an electrician, he can also consider working with other things. Faazel likes working as a floor layer, but also says that in the future he may do something different, unlike Fatos who says that he simply dreams of working as a floor layer.

\section{A Forced Choice}

The opportunity to get a job is constantly present in the students' choices regarding VET within MAE. However, the study shows that some students face greater consequences than shifting between a steady income and unemployment. Some of the FL students are immigrants without residence permits, and their future is unclear since they do not know if they will have the right to stay in Sweden. Having a job is a prerequisite for staying in Sweden. There is an understanding among these students that studying to become a craftsman leads to finding a job, and the choice of VET thereby becomes forced. Farid explains the vulnerable situation that he is in. He wants to study at university and work with computers, otherwise he will not be allowed to stay in Sweden. He says:

So, we get a residence permit, and we have to start working after upper secondary education, so we can't go to university. I really want to study computer programming, I like it, but... [...] My dream is that, maybe, next year I will start working, maybe I can buy an apartment and a car, after that I can start studying again, go to university and study programming, that's my dream.

An educational choice can be an expression of future vocational or occupational dreams. However, occupational dreams may mean something other than a dream job, like "to be able to stay in Sweden". The narrative presented by Faazel is similar in relation to the fact that the first thing mentioned about future vocational dreams is to stay in Sweden.

Interviewer: What is your future dream job?

Faazel: Just find a job [...] so that I can stay.

Interviewer:Is it the case that, if you don't get a job you have to go back?

Faazel: Yes, a little, yes... but it's not 100 percent, maybe... 30? That I have to go back but I have to find a job, I want to make more money, student grants and loans are not enough.

Interviewer: How will this education help you reach your goal of getting a job and staying?

Faazel: I think there is a lot of work in flooring; they build every day, everywhere, I think there is a lot of work.

Neither Farid nor Faazel talks about FL as their true dream job, and Farid even talks about preferring something else. But instead of pursuing his dream job he chooses a path that, from his point of view, seems more secure since the main goal is to stay in Sweden, not necessarily to work with what he loves. 


\section{The Idealistic Choice of Path}

The choice of education is sometimes expressed as being of greater importance than 'only' being a pragmatic choice or one of many possible paths in life. In this theme, it is expressed as an opportunity to do something more with one's life, or a choice based on a genuine interest, but it does not necessarily have to be a dream that the students have been thinking about all their lives. The idealistic path has both a knowledge idealistic aspect, where the interest in the subject itself is prominent, and a more societal idealistic aspect, in the sense that the students' driving force is to do good for society or 'give something back'. By contrast, the pragmatic choice certainly includes an element of the knowledge idealistic path regarding the dream of working as a craftsman, but there are nuanced differences between "I dream of working as a craftsman" and "I can imagine me working as a craftsman".

Within the framework of a knowledge idealistic path, the students' interest in the vocational subject in itself is raised as something greater than the knowledge needed to be able to do the job; knowledge has an intrinsic value. For AN students, it is the subject of healthcare and related areas: to learn more about how human biology and psychology work, about caring, nursing and medicine. For FL students, it can be indepth knowledge of the craft or aesthetic aspects of the job.

Among the AN students, the subject may imply an interest in learning more about people, or how to help people. Amir points out that he thought about what his future life could look like and that he chose AN because he wanted to learn more about man, mind and body. Alea mentioned something similar: "I hope that I get to learn everything, learn how to help people, learn Swedish and new Swedish words."

The burning interest may not have been found in the same embodied way among the FL students. Here, it is expressed as something that emerged in the desire to work as a craftsman. The FL occupation in itself was compared to other occupations within craftsmanship, and the possibility to go deeper and specialize is a reality. Filip says:

Well, it's floor laying! That's my dream and nothing else. If you think about the floor laying process there is, something, that I think is rather awesome, or fun, to restore old parquet floors, but I have also heard that that is the worst. But I think it would be a lot of fun, I mean, the results are huge! It's like, craftsmanship for real, you know...

There is also another, more general - rather than subject-specific - knowledge idealistic aspect that is focused on intrinsic values of knowledge. The students express that learning new things is fun and that this has a value in itself. An example of this is as An-Ni, who owns an acupuncture clinic and thought about becoming a physiotherapist, and who pointed out that her main reason for studying is due to her interest in learning new things:

I didn't choose this education to become a physiotherapist... No, no, no, it's because I want to learn new things, new things. It's not to become that, that's not the goal, no no. But learning new things, I may be able to supplement my 
knowledge and it can help me with my job and maybe in the future I can also work as an assistant nurse. But that is not the goal.

From a societal idealistic perspective, there are narratives of being allowed to give back to society in some way; that the feeling of job satisfaction derives to some extent from doing good for others, to working with a caregiving job, as Ajda puts it:

I have promised my aunt. 'Ajda, you will be a nurse in the future, if I pass away one day and do not exist, you will be a nurse.' And I will be! For my aunt is such a woman, she has helped a lot of lives. She is a nurse and during the period that I had depression it was she who fixed me, she made me well. So I told her I'll be a nurse, I will help others who are in the same situation, I like that.

Ajda's promise about the future is to give something back. Anna, who had worked as a care assistant, explained that her interest in the caregiving job came from the fact that her grandmother fell ill with cancer. She said: "I want to help other people, in a job that matters". Among the FL students, 'giving something back' was not an underlying reason for their educational choice, even though there were some who had also thought about becoming an assistant nurse.

\section{Discussion}

Studies that focus on vocational formation, in education or working life, run the risk of missing out on aspects of which initial driving force(s) drew the student towards a specific education programme or what influences the student's vocational identity formation (Billett, 2011; Hägerström, 2004). This is especially true when it comes to the decision to start studying as an adult. What this article tries to understand is why adult students engage in specific educational practices, and both defines and nuances the rationalities behind students' choice of vocational pathway. We argue that the sense of self is a cornerstone of learning a vocation, and that students' choice of pathway is both part of and subjugated to their sense of self, in relation to social perquisites.

The results show adult students' educational choices and pathways towards a vocational becoming, as well as the underlying rationalities. There are a variety of rationalities behind the choice of pathway, including previous experience, selfperception with regard to both prerequisites and possible futures, and advice from external parties. Each theme does not represent an individual student; rather, they are a compilation of different aspects of the students' statements. However, each theme brings together different rationalities that form the foundation of the students' sense of self in the educational context. This in turn guides their intentions, thinking and actions (Billett, 2006).

From the results, one might argue that there are only two general types of pathway: one characterized by idealistic imperatives and the other by pragmatic choices, grounded in more or less strict (or forced) societal requirements of getting a job. The rationalities tied to the more idealistic pathway are noticeably more tangible among 
the AN students. All AN students take, in one way or another, a knowledge- or societal-idealistic approach to their training, even if their stories vary in degree and intensity. There are also some knowledge- or aesthetic-idealistic intentions among the FL students, but nothing about giving back to others or working for society's best interests. Regardless of pragmatic or idealistic rationales, choices are dependent on the individual's experiences, goals, learning and personal trajectories, as well as social needs and imperatives (cf. Billett, 2011; Jørgensen, 2013).

\section{Choices and Pathways as Subjectivities}

Each pathway is its own subjectivity analogy, with defined and attributed characteristics and intentionality. In essence, these subjectivities constitute a form of intentionality identification when encountering everyday choices, in a school or training context. This is similar to Rothes et al's., (2014) argument about repertoire and its connection to identity. In this study, the findings show that the students' life situations offer different repertoires and create intrinsic and extrinsic motivations for choosing a specific VET programme.

The findings show that the subjectivities have both societal and personal connotations, and that future vocational identity is both something that the students identify with and what they want to identify with (Billett, 2010). Or, in line with Klope (2015), the choice is both towards a specific vocation and away from some other vocation. However, for many of the students, the choice of vocational education was not a choice of vocation per se, rather a step on the way towards another future (e.g. Jørgensen, 2013).

For adult students, the educational choice is also influenced by other aspects that are more in relation to the student's specific life situation. In some cases, it can even be more important than developing a vocational identity (e.g. Koniordos et al., 2001). These findings are similar to those of Rothes et al., (2014) or - as Assarsson and Sipos Zackrisson (2005) stressed - a path towards making a living, learning, earning credits and self-realization. We would argue that adult students' educational choices are influenced by the many different communities of which they are members and that contribute to the construction of their identity in one way or another (cf. Wenger, 1998), not forgetting the students themselves and the stories they tell (Wojecki, 2007). Therefore, the encounter with an educational context will influence the students' intentions, sense of belonging and sense of self, as well as where they see themselves in the future (cf. Billett, 2006).

\section{Comparing Choices and Pathways}

When comparing the students from the two programmes, it becomes apparent that the choice is also influenced by societal structures, symbols and identities that influence which positions are made available (Billett's, 2011; Dæhlen, 2005; Hägerström, 2004; van Tuijl \& van der Molen, 2015). One such difference concerns the pragmatic choice in relation to achieving a specific way of working. In general, the students say that they want to work 'practically', and vocational training gives 
them the opportunity to do so. Among the AN students this is expressed as different aspects of working with caregiving, and among the FL students as working as craftsmen - different communities of practice (CoPs) that are more extensive than, but also include, the AN or FL CoP. Since identity maintenance is something that happens across different CoPs (Billett \& Pavlova, 2005), one might argue that the CoP the students strive to become part of is more than just their vocation.

Another example is how the students talk about different educational or vocational paths in the future. which is influenced by their experiences of previous schooling or work, and by advice from study counsellors (cf. Borghan et al., 2015; Dæhlen, 2005; van Tuijl \& van der Molen, 2015). In theory, all students have access to all MAE in Sweden. However, FL students mentioned fewer educational alternatives and a narrower range, which seems to show a difference in their overall sense of self and their personal and social prerequisites, and in the educational and vocational opportunities presented to them. Nevertheless, one common feature of both FL and AN is that several of the students have recently immigrated to Sweden and are looking for a short educational path that leads to a job (cf. Andersson \& Muhrman, 2019). The FL students are more attuned to the idea of finding other jobs besides flooring, expressing more temporality in their vocational choice (cf. Jørgensen, 2013). The AN students, on the other hand, talk about vocational work or tertiary medicinal studies, although their educational choice does not include the basic requirements for further studies. These adult students view further studies as a possibility, but they lack important information about how to pursue such studies. Like Eriksson et al. (2018), we see a risk that this lack of information is leading to a reproduction of unequal class structures, where working class adults get working class jobs.

\section{Being Before Becoming}

Sense of belonging is clearly tied to externally identifiable identity markers, such as workwear, mastering skills, being in a workshop, having fun with colleagues and using specific tools (cf. Klope, 2015). Based on this, defining a community of practice where the students' peripheral trajectory originates can be troublesome. The students in this study are just at the beginning of their training for a vocation, but the sense of self that ties into the thought of "I am engaged in VET" or "I want to become this vocation" and their prior knowledge of the vocation create a process of identifying themselves with the vocation. In some way the students already are, albeit in various ways, their vocation at the start of their first VET course, in the sense that they identify themselves with their vocation. The sociocultural idea of vocational identity should not be seen as binary - outside or inside - but rather as a graded scale where the individual more or less belongs to, or participates in, the vocational centre, in terms of knowledge/abilities/experiences, sense of self and belonging.

Billett \& Somerville, (2004) write that "acknowledgement and privileging needs to be given to individuals' intentionality and subjectivity in considering how best workers might continue to learn and develop throughout their working 
lives" (p. 32), and the same goes for students within MAE VET. As our findings show, there is a multitude of themes regarding rationalities behind educational choices.

To conclude, this study has shown that identity formation is a process that is larger than vocational becoming within a vocational community of practice, since MAE studies involve students' whole being, including their personal identity trajectories as well as the vocational identity formation. When comparing the two programmes it becomes apparent that the educational choice is related to specific way of working but also to future educational or vocational pathways. These findings raise questions about how adult students perceive what it means to be a worker within their future vocation. A critical reflection on this study is that the methodology was limited to what could be captured with interviews. Additional observations with the students as well as interviews with the teachers might have enriched the understandings further. With this article, we hope to provide a foundation for a pedagogical discussion about adult students' intentions with their studies. Focusing on the great variety of how different subjectivities affect the students with regard to their future vocational becoming, we expand the existing research field in VET with new perspectives.

Authors' Contributions All authors contributed, principal author is Tobias Karlsson.

Funding Open access funding provided by Linköping University.

Data availability Data provided by the informants in the study is only available to the authors.

Code Availability Data provided by the informants in the study is only available to the authors.

\section{Declarations}

Ethics Approval Not applicable

Consent to Participate Participants in this study has signed a Participant Consent Form.

Consent for Publication Participants in this study has signed a Participant Consent Form.

Conflicts of Interest Not applicable

Open Access This article is licensed under a Creative Commons Attribution 4.0 International License, which permits use, sharing, adaptation, distribution and reproduction in any medium or format, as long as you give appropriate credit to the original author(s) and the source, provide a link to the Creative Commons licence, and indicate if changes were made. The images or other third party material in this article are included in the article's Creative Commons licence, unless indicated otherwise in a credit line to the material. If material is not included in the article's Creative Commons licence and your intended use is not permitted by statutory regulation or exceeds the permitted use, you will need to obtain permission directly from the copyright holder. To view a copy of this licence, visit http://creativecommons.org/licen ses/by/4.0/. 


\section{References}

Andersson, P. \& Muhrman, K. (2019). Marketization of vocational adult education in Sweden. I: Pedagogical concerns and market demands in VET. Proceedings of the 3rd Crossing Boundaries in VET conference Vocational Education and Training Network - VETNET. Valencia, Spain: Zenodo. 10.5281/zenodo. 2640958

Assarsson, L. \& Sipos Zackrisson, K. (2005). Iscensättning av identiteter i vuxenstudier. (Academic dissertation). Linköping: Linköping University

Billett, S. (2006). Work, Subjectivity and Learning. In S. Billett, T. Fenwick, \& M. Somerville (Eds.), Work, Subjectivity and Learning. Dordrecht: Springer.

Billett, S. (2010). Lifelong learning and self: Work, subjectivity and learning. Studies in Continuing Education, 32(1), 1-16. https://doi.org/10.1080/01580370903534223

Billett, S., \& Pavlova, M. (2005). Learning through working life: Self and individuals' agentic actions. International Journal of Lifelong Education, 24(3), 195-211. https://doi.org/10.1080/02601 370500134891

Billett, S., \& Somerville, M. (2004). Transformations at Work: Identity and learning. Studies in Continuing Education, 26(2), 309-326. https://doi.org/10.1080/158037042000225272

Billett, S. (2011). Vocational education, purposes, traditions and prospects. Springer.

Borghans, L., Golsteyn, B. H. H., \& Stenberg, A. (2015). Does Expert Advice Improve Educational Choice? PLoS ONE, 10(12), 1-28. https://doi.org/10.1371/journal.pone.0145378

Braun, V., \& Clarke, V. (2006). Using thematic analysis in psychology. Qualitative Research in Psychology, 3(2), 77-101. https://doi.org/10.1191/1478088706qp063oa

Clarke, V., \& Braun, V. (2017). Thematic analysis. The Journal of Positive Psychology, 12(3), 297298. https://doi.org/10.1080/17439760.2016.1262613

Dæhlen, M. (2005). Change in job values during education. Journal of Education and Work, 18(4), 385-400. https://doi.org/10.1080/13639080500327774

Eriksson, H., Högdin, S., \& Isaksson, A. (2018). Education and Career Choices: How the School Can Support Young People to Develop Knowledge and Decision-making Skills. Universal Journal of Educational Research, 6(9), 1900-1908. https://doi.org/10.13189/ujer.2018.060907

Ferm, L., Persson-Thunqvist, D. B. P., Svensson, L., \& Gustavsson, M. (2019). Vocational students' identity formation in relation to vocations in the Swedish industrial sector. Nordic Journal of Vocational Education and Training, 9(2), 91-111.

Hodkinson, P., Biesta, G., \& James, D. (2008). Understanding Learning Culturally: Overcoming the Dualism Between Social and Individual Views of Learning. Vocations and Learning, 1, 1-5. https://doi.org/10.1007/s12186-007-9001-y

Hägerström, J. (2004). Vi och dom och alla dom andra andra på komvux. [Academic dissertation]. Lund: Sociologiska institutionen.

Jørgensen, C. H. (2013). The role and meaning of vocations in the transition from education to work. International Journal of Training Research, 11(2), 166-183.

Klope, . (2015). I skuggan av ett yrke: Om gymnasieelevers identitetsskapande på hantverksprogrammet frisör. Stockholms universitet.

Knocke. W. \& Hertzberg, F. (2000). Mångfaldens barn söker sin plats. Stockholm: Arbetslivsinstitutet.

Koniordos S., Brown, A., Strietska-Ilina., O., Patiniotis, N. (2001). Changing vocational identities in Europe:reflections on how vocational identities are decomposed and reconstructed from the CzechRepublic and Greece. Paper presented at Fourth International Conference 'Vocational Education and Training Research', University of Wolverhampton, 16-18 July 2001. Retrieved: 2020-11-17 https://www.academia.edu/1012551/Changing_vocational_identities_in_Europe_ reflections_on_how_vocational_identities_are_decomposed_and_reconstructed_from_the_ Czech_Republic_and_Greece

Brinkmann, S. \& Kvale, S. (2015). InterViews: learning the craft of qualitative research interviewing. (3., [updated] ed.) Los Angeles: Sage Publications.

Lagercrantz All, K. (2017). Delaktighet- och lärprocesser i en yrkesutbildning: en studie av vuxna elevers erfarenheter av vård- och omsorgsutbildningen inom komvux. (Academic dissertation). Stockholm: Stockholm University

van Tuijl, C., \& van der Molen, J. H. W. (2016). Study choice and career development in STEM fields: An overview and integration of the research. International Journal of Technology and Design Education, 26, 159-183. https://doi.org/10.1007/s10798-015-9308-1 
Rothes, A., Marina, S., Lemos, M. S., \& Gonçalves, T. (2014). Motives and beliefs of learners enrolled in adult education. Procedia - Social and Behavioral Sciences, 112(2014), 939-948. https://doi.org/10.1016/j.sbspro.2014.01.1252

SGO, The Swedish government offices. (2007). The Swedish strategy for lifelong learning. A summary of principles and orientations. https://uil.unesco.org/i/doc/lifelong-learning/policies/sweden-the-swedish-strategy-for-lifelong-learning.pdf

SNAE (Swedish National Agency of Education). (2017). Läroplan för vuxenutbildningen. Reviderad 2017 [National curriculum for adult education. Revised 2017]. SNAE.

OECD. (2020). Learning for life. https://www.oecd.org/education/learningforlife.htm

Wenger, E. (1998). Communities of practice: Learning, meaning and identity. Cambridge University Press.

Wojecki, A. (2007). 'What's identity got to do with it, anyway?' Constructing adult learner identities in the workplace. Studies in the Education of Adults, 39(2), 168-182. https://doi.org/10.1080/02660 830.2007.11661547

Publisher's Note Springer Nature remains neutral with regard to jurisdictional claims in published maps and institutional affiliations.

Tobias Karlsson is a phd-student at the Department of Behavioural Sciences and Learning at Linköping University, Sweden. His research interests focus on vocational identity formation within the upper secondary municipal adult education in Sweden.

Karolina Muhrman is a senior lecturer of education at the Department of Behavioural Sciences and Learning at Linköping University, Sweden. Her research interests focus on the teaching of mathematics in vocational education, and marketisation of adult education.

Sofia Nyström is an Associate Professor in Education at the Department of Behavioural Sciences and Learning at Linköping University, Sweden. Her research interest focuses on the relation between education and work concerning arrangements for professional and vocational learning as well as identity formation using different theoretical perspectives. She is currently working on a research project concerning simulation-based training in VET. 